\title{
SEC Rule 10b-16 and the Regulation of Margin Credit
}

To foster the "informed use of credit," 1 Congress in 1968 passed the Truth in Lending Act, ${ }^{2}$ a comprehensive measure regulating consumer credit practices. The Act requires merchants and lending institutions to disclose credit terms to potential customers. ${ }^{3}$ The disclosure provisions, however, do not apply to transactions in which a broker or dealer furnishes credit to facilitate trading in securities or commodities accounts. ${ }^{4}$ Congress specifically exempted these "margin" credit transactions $s^{\bar{j}}$ with the understanding that the Securities and

1. 15 U.S.C. $\$ 1601$ (Supp. V 1975).

2. 15 U.S.C. $\$ \S 1601-1681 \mathrm{t}$ (1970 \& Supp. $V$ 1975). The legislative history can be found in Consumer Credit Protection Act: Hearings on H.R. 11601 Before the Subcomm. on Consumer Affairs of the House Comm. on Banking and Currency, 90th Cong., Ist Sess. (1967) [hereinafter cited as 1967 House Hearings]; Truth in Lending-1967: Hearings on S. 5 Before the Subcomm. on Financial Institutions of the Senate Comm. on Banking and Currency, 90th Cong., 1st Sess. (1967) [hereinafter cited as 1967 Senate Hearings]; H.R. REP. No. 1040, 90th Cong., 1st Sess. (1967), reprinted in [1967] U.S. Cone CoNG. \& AD. Niws 1962 [hereinafter cited without cross-reference as 1967 Hotse REPORT]; S. REl. No. 392, 90th Cong., Ist Sess. (1967) [hereinafter cited as 1967 Senate Report]; 113 Cong. Rec. 18399-424 (1967); 114 CoNG. REc. 1421-60, 1582-1618, 1831-57 (1968).

3. The Truth in Lending Act is divided into four major sections that deal, respectively, with disclosure of consumer credit costs, control of extortionate credit transactions, restrictions on garnishment, and creation of a National Commission on Consumer Finance. The disclosure title requires creditors to inform "each person to whom consumer credit is extended and upon whom a finance charge is or may be imposed" of the annual percentage rate represented by the total finance charge. 15 U.S.C. \$ 1631 (1970). In addition, the title mandates disclosure of the methods for determining finance charges and of the penalties for late payment. Id. $\$ \S 1636-1639$. It also requires a "description of any security interest held or to be retained or acquired by the creditor in connection with the extension of credit, and a clear identification of the property to which the security interest relates." Id. $\$ 1638(\mathrm{a})(10)$.

The maximum penalty for willful and knowing failure to disclose the specified credit information is a fine of $\$ 5000$ and/or imprisonment for one year. Id. $\$ 1611$. For all noncriminal violations, the Act prescribes a fine of twice the amount of the charge in queston (but not less than $\$ 100$ nor more than $\$ 1000$ ), as well as liability (where the consumer's suit is successful) for court costs and reasonable attorney's fees. Id. $\$ 1640(a)$ (Supp. V 1975). Creditors are allowed a defense of unintentional and bona fide crror if they maintain "procedures reasonably adapted to avoid any such error." Id. $\$ 1640$ (c).

4. 15 U.S.C. $\$ 1603(2)$ (1970). See 1967 SENATE RePorT, supra note 2, at 9; 1967 House REPORT, supra note 2, at 28.

5. "Margin" trading is leveraged speculation on credit in securities or commodities. Credit usually is extended by a broker; occasionally, it is extended by a bank or other lending institution. In "long" transactions the customer puts up part of the purchase price, borrows the balance on margin, and uses the securities or commodities thus purchased as collateral for the margin loan. In "short" sales the customer sells stock he does not own. The margin loan thus consists of borrowed stock; collateral for the loan is provided by the funds realized on the sale of this stock. For a simple but comprehensive explanation of various types of margin transactions, see Merrill Lynch, Pierce, Fenner \& 
Exchange Commission (SEC) would require "substantially similar disclosure." ${ }^{6}$ The Commission in 1969 responded to this congressional mandate by promulgating Rule $10 \mathrm{~b}-16$, which regulates disclosure of credit terms in margin transactions. ${ }^{7}$

The Rule operates simultaneously as consumer legislation, a securities law, and part of the federal scheme of margin regulation. ${ }^{8}$ It fulfills its various functions unsatisfactorily. This Note contends that the Rule does not reflect the philosophy of the Truth in Lending Act and fails to offer effective protection to margin customers. The Note sug-

Smith, Inc., What Is Margin? (March 1976) (pamphlet on file with Yale Law Journal) [hereinafter cited as What Is Margin?]. See generally 2 L. Loss, Securities Regulition 1248-56 (2d ed. 1961); 5 id. 3264-73 (2d ed. Supp. 1969).

Minimum cash deposits required for margin transactions have varied from a low of $40 \%$ to a high of $100 \%$ in the 42 years the federal government has regulated margin. See 2 L. Loss, supra at 1244-48 (2d cd. 1961); 5 id. at 3262-64 (2d ed. Supp. 1969). Currently, a $50 \%$ deposit is required for margin transactions in most securities. See 12 C.F.R. $\$ \$ 207.5,220.8,224.1$ (1976). Margins in the conmodity markets tend to be much lower. See generally 1 A. Bromiserg, Securities Law: Fraud $\$$ 4.6(415), at 82.141-.142 (1975).

6. 1967 SENATE REPORT, supra note 2 , at 9.

7. 17 C.F.R. $\$ 240.10 \mathrm{~b}-16$ (1976). The rule requires disclosure of credit terms at the time a margin account is opened, quarterly reports to the customer at the end of each quarter, and advance notice of any changes in the terms and conditions of credit.

There has been little academic or judicial discussion of Rule 10b-16. See $1 \mathrm{~A}$. BrosBERG, supra note 5, $\$ 2.2$ (510), at 22.14 (1975) (summarizing requircments of Rule); 51 N.Y.U.L. REv. 1050 (1976). The Rule has been the subject of two "no-action" letters by the SEC, see Freedman, Silverberg \& Lewis, Inc. (June 9, 1972); General Electric Co. (June 17, 1971), and three court decisions, see Liang v. Dean Witter \& Co., 540 F.2d 1107 (D.C. Cir. 1976); Stephens v. Reynolds Sec., Inc., 413 F. Supp. 50 (N.D. Ala. 1976); Tilly Foster Real Estate Corp. v. Shearson, Hammill \& Co., [1973 Transfer Binder] FED. SEC. L. REP. (CCH) If 94,073 (S.D.N.Y. 1973).

8. The current federal system of margin regulation has three major aspects. The first deals with margin as a technique of securities trading and strives to prevent the use of margin as a manipulative device to deceive the public. See S. REP. No. 1455, 73d Cong., 2d Sess. 11 (1934). The second treats margin as a factor in the level of speculation and, hence, of market activity and attempts to moderate excessive price fluctuations by regulating the amount of margin credit outstanding. See H.R. REP. No. 1383, 73d Cong., 2d Sess. 8 (1934). The final and broadest aspect of the federal regulatory scheme views margin as contributing to the size of the money supply and seeks to control margin in order to influence the economy as a whole. See, e.g., S. Doc. No. 82-123, 82d Cong., 2d Sess. (1952).

This tripartite scheme of margin regulation draws its statutory authority from the Sccurities Exchange Act, which empowers the Federal Reserve Board (FRB) to set initial stock margin levels and to control maintenance calls (the demand for additional collateral by the lender), 15 U.S.C. $\$ 78 \mathrm{~g}(1970)$, and from the Commodity Exchange Act, which enables the Commodity Exchange Commission to alter or supplement the exchange-established margin requirements, 12 U.S.C. $\$ 12 a(7)$ (Supp. V 1975). The FRB, however, has never exercised its full authority to regulate margin calls. Hence, most of the stock exchanges have superimposed their own rules on those of the FRB, and some of these private regulations have been clevated to quasi-statutory status. See 2 L. Loss, supra note 5, at 1265-67 (2d ed. 1961); 5 id. at 3310-11 (2d ed. Supp. 1969); Lowenfels, Implied Liabilities Bascd Upon Stock Exchange Rules, 66 CoLum. L. REv. 12 (1966); Note, Civil Liability of a Broker for Failure to Enforce Margin Requirements, 10 WILLAMETTE. L.J. 72, 78-83 (1973). A detailed analysis of the effect of Rule 10b-16 on the federal system of margin regulation is beyond the scope of this Note. 
gests that Rule $10 \mathrm{~b}-16$ be eliminated and that disclosure of interest rates and other terms of credit in margin accounts be regulated by the Truth in Lending Act. Margin credit disclosures considered fraudulent under the Securities Exchange Act of $1934^{\circ}$ would be redressable under procedures already provided by that Act.

\section{Truth in Lending and the Genesis of Rule 10b-16}

The Truth in Lending Act is principally concerned with the financially unsophisticated consumer. This solicitude is especially evident in the interest rate section of the Act: ${ }^{10}$ it requires easily comprehensible rate disclosures, ${ }^{11}$ emphasizes enforcement by various governmental agencies so that those injured need not hire lawyers, ${ }^{12}$ and provides an automatic damage formula linked to the interest charge in order to eliminate the necessity of proving money damages. ${ }^{13}$ Concern for the financially naive is also apparent from the types of transactions exempted from coverage. The Act does not apply, for example, to extensions of credit for business or commercial purposes, for projects involving amounts over $\$ 25,000$, or for "[ $t$ ]ransactions in securities or commodities accounts by a broker-dealer registered with the Securities and Exchange Commission." 14

During hearings before the Senate subcommittee considering the Truth in Lending bill, James L. Robertson, Vice Chairman of the Board of Governors of the Federal Reserve System, urged that margin transactions not be excluded from Truth in Lending. In the view of the Federal Reserve, Robertson stated, there was "nothing to provide

9. 15 U.S.C. $\$ \$ 78 \mathrm{a}-78 \mathrm{kk}$ (1970 \& Supp. V 1975).

10. The provisions of the Act that pertain to interest rates can be found at 15 U.S.C. $\$ \S 1601,1605-1607,1631-1640$ (1970 \& Supp. V 1975).

11. Id. $\$ \$ 1605-1606,1631-1639$ (I970 \& Supp. V 1975). See 1967 House ReporT, supra note 2 , at 18 .

12. 15 U.S.C. $\$ 1607$ (1970). Furthermore, although agency enforcement was viewed as the primary protection for naive consumers, 1967 HOUSE REPORT, supra note 2, at 18, the Act established a private right of action for nondisclosure violations "in connection with any consumer credit transaction," 15 U.S.C. $\$ 1640$ (a) (1970). The section was brondened in 1974 to read "any creditor who fails to comply with any requirement . . . with respect to any person is liable to such person." Id. $\$ 1640$ (a) (Supp. V 1975).

13. 15 U.S.C. $\$ 1640$ (1970 \& Supp. V 1975).

14. Id. $\$ 1603$ (1970 \& Supp. V 1975). Additional exemptions include cxtensions of credit to governmental entities, transactions under certain public utility tariffs, and transactions "primarily for agricultural purposes in which the total amount to be financed exceeds $\$ 25,000 . " I d$. It was felt that most of these credit transactions involved parties who, because of their status or wealth, would have the financial sophistication or economic power to enable them to bargain for needed disclosures. Sec, e.g., 1967 Senate Hearings, supra note 2, at 677 (Sen. Proxmire). 
comparable protection in [the margin] area." ${ }^{15}$ Responding to a request for its opinion, the SEC told the subcommittee that it had the authority to regulate some margin transactions. ${ }^{16}$ In the report that later appeared, the subcommittee's parent committee informed the Senate that although margin transactions were exempted from the provisions of the Act, the committee intended the SEC "to require substantially similar disclosure by regulation as soon as it is possible to issue such regulations."17

It is unclear whether Congress intended that the SEC merely implement a disclosure rule identical to the provisions of Truth in Lending, or whether the SEC received a broad mandate to develop disclosure provisions designed to protect investors engaged in the specialized field of trading on margin credit. ${ }^{18}$ In drafting the new Rule 10b-16 the SEC took the former course; the Rule was designed as a consumer protection measure. The Commission described the Rule as having been

15. 1967 Senate Hearings, supra note 2, at 676 (James L. Robertson).

16. The Senators believed that the SEC already possessed the power to require the disclosure of interest rates. See 1967 Senale Hearings, supra note 2, at 677 (statement of Sen. Proxmire). Nonetheless, the subcommittee asked the SEC about its capacity to regulate stock and commodity margin. The Commission replied that it had authority to require interest rate disclosure by broker-dealers, reminded the subcommittee members that it had no direct jurisdiction over commodity transactions, and revealed that it was conducting discussions with the various stock exchanges about the development of private rules for margin account disclosures. Id. at 685-86 (letter of Manuel F. Cohen, Chairman of SEC). The Commission added that "[w]hatever may eventuate within the exchanges in this area, the Commission is prepared to adopt its own rules to whatever extent may be necessary." Id. at 686 .

17. 1967 SENATE REPORT, supra note 2, at 9. The committee's phraseology is ambiguous in two respects. The first is purely technical or linguistic and concerns the meaning of "substantially similar." These words do not indicate precisely whether Congress wanted requirements facially equivalent to those in Truth in Lending or whether it desired that the Rule 10b-16 regtlations follow the spirit of the Act, even if that meant facially different rules. The second ambiguity is substantive and concerns, on the one hand, whether Congress intended to protect certain types of credit transactions or only a certain class of credit customers. On the other hand, it is uncertain whether Congress was addressing any problem other than nondisclosure of interest rates, that is, whether Congress intended the SEC to regulate margin maintenance calls. Cf. note 28 infra (discussing margin maintenance calls). It appears that interest rates may have been the only real concern. See notes 11-13 supra \& note 19 infra.

18. Both possibilities represent a shift from the earlier position of the drafters, which appears to have been that margin traders are sophisticated investors who do not need statutory protection. See 1967 Senate Hearings, supra note 2, at 677 (Sen. Bennett). The initial plan had been to leave margin customers in both security and commodity transactions out of the regulatory scheme entirely. Only on the last day of the hearings did the subcommittec begin the reconsideration of the excmption that led to the eventual decision to direct the SEC to control disclosures in relation to security margin accounts. See id. at 676-7\%. The fact that the Senators did not provide for regulation of commodity accounts is somewhat puzzling, since there are no indications that the legislators considered commodity speculators different from, or less deserving of protection than, security speculators. The rather sparse legislative history suggests that congressional intent with regard to regulation of margin transactions is conflicting. 
adopted in response to a congressional "mandate" arising under the Truth in Lending Act. ${ }^{19}$

The consumer protection orientation of the Rule is revealed most clearly in the Commission's explanatory release, which outlines the benefits of disclosure to margin customers ${ }^{20}$ in language similar to that of the preamble of the Truth in Lending Act. ${ }^{21}$ In at least some respects, Rule 10b-16 seems to adhere to the system set up by the Act. ${ }^{22}$ Nonetheless, the scheme of margin disclosure regulation established by Rule $10 \mathrm{~b}-16$ fails ultimately to reflect congressional intent as manifested in Truth in Lending.

\section{Rule 10b-16 and the Protection of Margin Customers}

Rule 10b-16 functions inefficiently as a consumer protection securities law. The disclosures it requires are of limited value to margin customers, and the remedies it provides are of equally limited effectiveness. Moreover, the use of section 10(b) securities antifraud principles to enforce an essentially consumer-oriented provision imposes restrictions on a Rule 10b-16 cause of action that cripple its ability to offer meaningful consumer protection.

Rule $10 \mathrm{~b}-16$ is an attempt to protect a special type of investor, the margin trader. Although the provisions for disclosure of interest charges found in the Truth in Lending Act exhibit an intention to protect purchasers of consumer goods, Rule $10 \mathrm{~b}-16$ is aimed at relatively wealthy and financially sophisticated individuals engaged in a

19. Securities Exchange Act Release No. 34-8773, December 16, 1969, 34 Fed. Reg. 19,717 (1969).

20. The release said of $10 \mathrm{~b}-16$ :

The rule requires an initial disclosure and periodic disclosures. The initial disclosure is designed to insure that the investor, before his account is opened, understands the terms and conditions under which credit charges will be made. This will enable him to compare the various credit terms available to him and to understand the methods used in computing the actual credit charges. The periodic statement will inform the investor of the actual cost of credit and, with the aid of the initial disclosure, enable him to accurately assess that cost.

Id. (emphasis added).

21. As Congress originally stated the purpose of the Act:

The informed use of credit results from an awareness of the cost thereof by consumers. It is the purpose of this subchapter to assure a meaningful disclosure of credit terms so that the consumer will be able to compare more readily the various credit terms available to him and avoid the uninformed use of credit.

15 U.S.C. \$ $1601(1970)$.

22. The Rule requires interest rate disclosure similar to that of Truth in Lending, compare 17 C.F.R. $\$ 240.10 b-16(a)(1)$ (1976) with 15 U.S.C. $\$ 1601$ (Supp. V 1975), and appears on its face to grant broad standing to potential plaintiffs through prohibition of violations "in connection with any securities transaction," 17 C.F.R. $\$ 24.10 b-16(2)$ (1976). Compare id. with 15 U.S.C. $\$ 1640$ (a) (1970). 
complex and speculative investment activity requiring specialized information. ${ }^{23}$ It is therefore not surprising that the provisions of the Rule differ in some respects from those of the Act. The main difficulty with the Rule is not that it fails to mimic the Act, however, but rather that as a prophylactic consumer protection measure it falls far short of providing margin customers with the facts necessary for the "informed use of credit."24

\section{A. Disclosure}

Margin traders and the consumers protected by the Truth in Lending Act need different information to make informed decisions. The consumer purchases goods or services on time; his need is for information concerning the cost of using a delayed payment option. Since a retail consumer is not normally trained in financial matters, he must have access to a clear, simple explanation of the terms of the loan and of the practical effect of these terms on the eventual total cost of his purchase. $^{25}$ The Truth in Lending Act attempts to meet these needs and to promote informed use of credit by requiring lenders to disclose, specifically and uniformly, all interest and finance charges accompanying a consumer credit transaction. ${ }^{26}$

The margin trader is, in contrast, engaged in a specialized investment activity. He needs information in addition to the interest charges on his margin account. ${ }^{27}$ Disclosure requirements for margin creditors,

23. Margin credit differs significantly from other consumer credit. The Act was intended to cover credit used to purchase property, goods, or services "for personal, family, household, or agricultural purposes," 15 U.S.C. $\$ 1602(\mathrm{~h})(1970)$, and the credit account was to be repaid in regular installments. The Rule covers credit used to finance speculation in the securities markets. Although finance charges are computed and posted periodically in margin accounts, payments to reduce the balance are not required. Instead, margin customers normally eliminate their indebtedness only when closing out the transactions that gave rise to the loan. Since many margin speculators trade constantly, they carry debit balances at all times. Those who extend margin credit do not demand periodic repayment because their lien on the securities or commodities bought (or the short sale proceeds received and deposited with them) is generally worth more than the amount of the margin loan, which is extended for only a specified percentage of the purchase or sales price.

24. 15 U.S.C. $\$ 1601$ (Supp. V 1975).

25. One of the main purposes of credit cost disclosures under the Truth in Lending Act is to enable financially unsophisticated families to budget their credit charges more successfully and thus to avoid financial embarrassment. See, e.g., 1967 SENATE REPorT, stipra note 2, at 1 .

26. 15 U.S.C. $\$ \S 1631-1632,1636-1639$ (1970 \& Supp. V 1975). The Federal Reserve Board has promulgated regulations that prescribe with precision the methods by which disclosures must be made to borrowers. See 12 C.F.R. $\$ \$ 226.1-.8$ (1976) ("Regulation Z," isstled pursuant to 15 U.S.C. $§ 1604$ (1970)); id. $\$ \S 226.101-1002$ (interpretations of Regulation Z).

27. Because margin principal and interest are not due in regular installments, see note 23 supra, as is the case with other consumer credit, there is little need from a budget- 
insofar as they are deemed necessary, should therefore be less concerned with simplicity and clarity and more concerned with providing the specialized information required by the margin trader. For the investor trading on margin, the most important information about credit terms is the amount of collateral he must maintain on his margin loan before the lender will make a margin call. ${ }^{28}$ The investor prefers to know the exact conditions under which the lender will call for more collateral, and this was likely an important factor in the Commission's drafting of the Rule. ${ }^{29}$

Disclosure under Rule 10b-16 differs from that under the Truth in Lending Act in ways that reflect the differences between consumer and margin creditors. The Rule merely requires brokerage houses to disclose the interest rate on margin loans; it does not define the method of computing total finance charges with the same specificity as the

ing point of view to know what the interest charges are. See id.; cf. note 25 supra (budgeting value to other consumers of interest rate disclosures). The interest charged on the margin loan is for the most part perceived only indirectly by the customer, since interest is not paid to the broker directly but added to the existing debit balance. The accumulated interest charges affect the client only when he sells (lessening his profit on the transaction) or when the debit balance becomes so large that a margin maintenance call arises. In most instances a margin call occurs not because of accumulated interest, but because securities prices are moving counter to the client's position in the market. Margin call standards are thus usually of greater concern to him than the interest rate, since the former alone involves tender of additional cash or a forced sale. This judgment was implicit in the SEC's decision to include margin call standards as one of the categories to be disclosed in Rule $10 \mathrm{~b}-15$ and in the correlative relaxation of interest cost disclosure procedures. Interviews with current and former SEC officials involved with drafting of Rule 10b-16 (notes on file with Yale Law Journal) [hereinafter cited as Interviews]. Nonetheless, disclostre of interest rates would at least aid the consumer in comparing the margin account terms of various brokerage houses. See Liang v. Dean Witter \& Co., 540 F.2d 1107, 1111 (D.C. Cir. 1976).

28. If the market value of the collateral declines significantly, the lender will ask for additional funds. This demand is known as a margin maintenance "call." If the call is not met, the existing collateral is liquidated to the extent necessary to pay off the margin loan. In most cases, the margin call is timed so that the original cash tendered is sufficient to protect the lender from loss. Because margin creditors are virtually assured of the safety of their loaned funds, interest rates fluctuate only slightly above the broker's call rate, which is generally $.25 \%$ to $.5 \%$ under the prime. See Wall St. J., Dec. 7,1976 , at 39 , col. 5 .

29. The consequence of such a disclosure in a thcoretical margin system would be to allow the margin trader to arrange his portfolio in such a way as to permit him to meet the request for more collateral without serious disruption of his other investment plans. Practically, however, this portfolio adjustment is not possible because the other unascertainable variable is the rate of price movement in the market. See note 39 infra. Even those drafting the Rule questioned the benefits of the disclosure it mandated. See Interviews, supra note 27. Many recent commentators have expressed skepticism about the relevance and usefulness to investors of much of the disclosure required generally by the securities laws or specifically by the SEC. See, e.g., H. MANNE, INSIDER TRAding ANd THE Stock MARKet (1966) (inside information); Benston, The Effectiveness and Effects of the SEC's Accounting Disclosure Requirements, in Economic Policy aNd THE REgulation of Corporate Securities 26 (H. Manne ed. 1969) (accounting); Kripke, The SEC, the Accountants, Some Myths and Some Realities, 45 N.Y.U.L. REv. 1151 (1970) (accounting). 
Act. ${ }^{30}$ On the other hand, the Rule requires disclosure of the standards brokerage houses use to determine when they will make margin maintenance calls; the Act, of course, contains no similar requirement. ${ }^{31}$ Yet despite these attempts to accommodate the needs of margin creditors, the Rule fails to provide useful information and has costly repercussions on the market for margin credit.

The first judicial consideration of Rule 10b-16's disclosure requirements concerning the timing of margin maintenance calls was in Liang v. Dean Witter of Co. ${ }^{32}$ Under the reasoning in Liang, if a brokerage firm's system of margin calls is purely discretionary, it need communicate to customers opening a margin account no more than the presence of such discretion. ${ }^{33}$ If, on the other hand, the system of the

30. Compare 17 C.F.R. $\S 240.10 \mathrm{~b}-16$ (1976) with 12 C.F.R. $\S \S 226.1-.8$ (1976) (Regulation Z). See note 26 supra.

31. The legislative record of the Truth in Lending Act evidences no intent to control margin beyond requiring disclosure of interest costs of margin loans. This conclusion is buttressed by the history of a section of the Truth in Lending bill proposed by the House Subcommittee on Consumer Affairs that would have contained a provision for regulation of margin levels in the commodity markets. See 1967 House Hearings, supra note 2, at 5, 26. Witnesses at the hearings generally agreed that a bill regulating disclosure of interest rates charged to consumers was not the proper context for such a provision, see id. at 599-658, and the proposal was dropped by committee amendment, see 114 Conc. REc. 1423,1435 (1968). The expunging of this section by the committee strengthened the Act's nature as a purely interest-rate oriented disclosure law. The SEC staff view, as it began work on Rule $10 \mathrm{~b}-16$, was that the Rule was intended by Congress to operate as a consumer protection measure regulating disclosure of the costs of margin credit. See Interviews, supra note 27.

32. 540 F.2d 1107 (D.C. Cir. 1976), discussed in 51 N.Y.U.L. Rev. 1050 (1976). Plaintiffs had signed a standard form "Customer's Agreement" supplied by defendant broker Dean Witter, in which the defendant was authorized to require additional collateral if necessary to protect itself. The Liangs, whose securities were liquidated when a margin call was not met, alleged a violation of the Rule. 540 F.2d at 1109-10.

In remanding the case, the circuit court stated that Rule $10 \mathrm{~b}-16$ did not require the formulation of any particular margin call standards by brokerage houses. The Rule merely prescribed disclosure of whatever standard was employed. Id. at 1111 . If the decision to make a margin maintenance call was truly an individual one made without any guidelines, the disclosure made by Dean Witter would have been sufficient. Id. at 1111-12. If, however, the brokerage firm had developed standards for timing a margin call, even if they were rule-of-thumb standards irregularly applied, they should have been revealed to customers. Id. at 1112 .

33. The court's definition of a discretionary system was not enlightening. The court suggested that a "firm may choose to operate on an entirely individual customer basis, without any general internal guidelines whatsoever; accordingly, it would only have to disclose that discretion is its sole guide." 540 F.2d at $1111-12$. Because the nature of the disclosure required will hinge on the presence or absence of broker discretion, line-drawing problems caused by the court's less than precise definition will influence the outcome of many cases.

It is possible that other courts will interpret Rule $10 \mathrm{~b}-16$ 's disclosure requirements differently. It could be argued that a statement like Dean Witter's, which merely announced that the firm could require additional collateral at its discretion, fulfilled the disclosure requirement. The Liangs were put on notice that there were no set standards. If they were not willing to put up with the uncertainty, they could go to another broker.

A reading of Rule $10 \mathrm{~b}-16$ slightly different from that of the Liang court has already 
brokerage house is not wholly discretionary, ${ }^{34}$ it has two choices. It can adopt and disclose a purely mechanical credit system that treats all customers alike. Alternatively, the brokerage house can use and disclose a "sliding scale" system that embodies distinct maintenance call standards for different classes of margin customers.

In none of the situations contemplated by the reasoning in Liang would disclosure be likely to provide much assistance to margin clients. The revelation that a system is purely discretionary would not indicate to customers when they might get a margin call, the principal information that margin customers want. ${ }^{35}$ Further, disclosure of a "sliding scale" standard, although seemingly more revealing, would probably not be helpful either. The value of such information is questionable in view of the likely complexity of the sliding-scale formula, ${ }^{36}$ the

been suggested in 51 N.Y.U.L. REv. 1050, 1063-64 (1976). The author proposes a "factor test" of compliance, in which brokers must disclose all the relevant factors in their potential margin call decisions. Following this procedure, even a broker using only discretion as a guide would have to reveal the multiplicity of elements constituting that rather vague mental stance. The author states that "[u]nlike the Liang test, the factor test would require all brokers to make the meaningful disclosure of collateral policies which rule $10 \mathrm{~b}-16$ was designed to provide." Id. at 1063. Practical objections, however, come to mind. For example, the factor test requires disclosures even more complex than those currently contemplated by the courts. See notes 36 \& 37 infra (quoting broker disclosure letter).

34. A defendant normally would not find it difficult to convince the court that it uses a wholly discretionary system. Although the Liang court did not discuss burden of proof, it seems that the plaintiff would have to demonstrate the existence of a nondiscretionary system. This is likely because of policy reasons, since courts would probably not want to make it too easy to bring such potentially expensive and annoying suits. Even if the burden were placed on the brokerage house, however, it could probably be met by citing examples of other customers who were not given margin calls according to any postulated set of guidelines.

It is of course possible that many firms would have some general internal policy that would be manifested in a pattern of discoverable behavior. Insofar as this is so, and insofar as the existence of such a mode of brokerage operations would provide a basis of liability in Liang situations, Rule 10b-16 provides incentives to follow a discretionary policy, or at least to deviate enough from general standards to create the appearance of a discretionary policy.

35. See pp. $377-78$ and notes 28 \& 29 supra.

36. If such a standard were reduced to a formula, it might be-or might easily be made-so abstruse that one would need to make complicated computations in order to deal with it. This would be especially true if the formula dealt with different classes of margin customers rather than treating all accounts equally.

Illustrative of the problems involved is this description of a sliding-scale formula that a brokerage house recently provided to its customers under Rule 10b-16:

In order to verify interest charges, the average daily net debit balance must first be ascertained for each interim interest period. This may be done as follows: Mfultiply each NET debit balance by the number of days the balance remains unchanged during the interim interest period. (The DEBIT balance for EACH DAY during the interim interest period must be accounted for.) Total these results and divide the sum by the number of days in the interim interest period. The quotient is the average daily net debit balance for your account for each interim interest period. 


\section{possibility that discretionary elements would persist in the announced standards, ${ }^{37}$ and the difficulty of monitoring the position of one's ac-}

The amount of interest charged for each interim interest period can then be verified by using the following formula:

$\begin{aligned} & \text { Average daily } \\ & \text { debit balance }\end{aligned}$
$=\begin{gathered}\text { Annual rate } \\ \text { of interest } \\ \text { Interest } \\ \text { charged }\end{gathered}$

The total interest charged for the monthly interest period is the sum of the interest charged for each interim interest period within the monthly interest period as computed in accordance with the above formula. Because the interest charges disclosed on any account statement are for a period from the 20th of the preceding month through the 19th of the month to which the statement relates, you should retain your prior month's statement for use in connection with the current month's statement, as well as for preparing your income tax returns.

Credit Charges and Margin Requirements (1977) (letter of brokerage firm to its margin customers, drafted after Liang) (on file with Yale Law Journal) [hereinafter cited as Disclosure Letter].

Such a formula is not impossible to manipulate in order to find the interest charges imposed on an account. It certainly involves a great deal more complexity, however, than a routine truth-in-lending interest rate disclosure. Even if the formula were relatively simple, the fact that interest rates disclosures under Rule $10 \mathrm{~b}-16$ are not required to adhere to any particular format, cf. note 26 supra (listing sections of Truth in Lending Act and accompanying regulations that explain precisely how interest charges disclosed are to be computed), means that it may be very difficult to apply the formula usefully, since the disclosed interest rate may not reflect actual total interest charges. The possible different computations of interest charges would at the very least make margin account comparisons for margin customers rather complex. Complexity in using the formula would be further increased by the fact that interest rates charged on the account are constantly fluctuating along with the prime rate. See note 28 supra. Careful prediction of the status of an account is impossible. Such an outcome would conflict with the congressional intent in the Truth in Lending Act, which looked toward simple disclosures that could be easily used for comparisons and personal financial planning. See notes 11 \& 25 supra.

37. The standards announced could simply be guidelines or a formula accompanied by a set of definitions or categories. Brokerage house discretion would be inherent in distinctions drawn upon the basis of such factors as "high credit rating," "good customer," and "likelihood of repeated transactions."

Onc of the first disclosures under the Liang interpretation of the Rule reflects some of these categories:

\section{LIENS AND ADDITIONAL COLLATERAL}

This firm may require you to deposit additional collateral in accordance with the Rules and Regulations of the Federal Reserve Board, the New York Stock Exchange, Inc., the American Stock Exchange, Inc., other national securities exchanges and associations, or any other regulatory agency having jurisdiction. [Firm name deleted] has a policy of periodically reviewing each account in which the equity, calculated without giving value to certain over-the-counter and low-priced securities, falls below $35 \%$ of the outstanding debit, or where concentration or other factors are deemed to warrant review. This policy contemplates the maintenance of equity in an account above that required by any regulatory organization having jurisdiction over this firm, and the firm examines each such account on an individual basis giving consideration to a number of factors such as the marketability of the securities in the account, the frequency of activity, the length of time the account has been open and concentration in particular issues. Different weight may be given to these factors in reviewing different accounts, and [firm name deleted] in its sole discretion may, but shall have no obligation to, require additional collateral on the basis of the review.

Disclosure Letter, supra note 36 (emphasis added). 
count comprehensively enough to apply the formula. ${ }^{38}$ Moreover, uncertainty over future market conditions is such an important consideration in determining the likelihood of margin calls under any standard that, even when a customer is perfectly informed of the circumstances under which margin calls will be made, he is still subject to a sizeable economic risk. ${ }^{39}$ Additionally, competition among brokers and uncertainty concerning market conditions make it unlikely that brokers will employ a purely mechanical maintenance call system, ${ }^{40}$ even if such a system would arguably be of some use to customers attempting to budget their resources.

Hence the disclosure requirements of Rule 10b-16 will do little to protect margin investors. First, little may be disclosed, and what is disclosed may be incomprehensible. Second, competitive forces and the desire to find the surest means to avoid liability and expense may push brokerage houses toward adopting and disclosing purely discretionary

38. Since the value of the stocks in the account would be constantly changing, proximity to a margin call would fluctuate in response. The only way to be certain of the position of the account would be to watch market prices continually, calculator in hand, always aware of changes in interest rates that would raise the debt level in the account. See note 36 supra.

Adding to the difficulty of following the dual factors of market value of securities and increasing level of debt is the existence of a "Special Miscellancous Account," which is used by many brokers for their customers in connection with the "general" margin account containing the securities. See 12 C.F.R. $\$ 220.4$ (1976). Any excess funds credited to the general account or generated through market appreciation are transferred to the Special Miscellaneous Account where they may be used for later purchases, even though such purchases through the general account would require the tender of additional cash or collateral. See What Is Margin?, supra note 5, at 8-9, 10-11. The Special Miscellaneous Account, whose balance also varies periodically, must be reckoned with in trying to ascertain proximity to a margin call.

39. Interest charges and allowable debt-equity ratios are only one part of the margin call equation. The controlling and immediate cause of a margin call is always the movement of stock prices. Hence, even if a margin client knew under exactly what conditions a call would come, he could still not estimate the timing of the margin call unless he knew the direction and rate of market movements. Such knowledge, though assiduously sought, is seldom gained. A customer could thus not use his Rule $10 \mathrm{~b}-16$ disclosures to great advantage in financial planning. For if he tried to keep his assets in less liquid, higher yielding investments until a margin call occurred, he would have to beat the risk of an adverse market move rendering such funds necessary before he had anticipated. In this respect, he would be little better off than the less informed margin customers who had not known under what conditions they would get a margin call. The only advantage would be to those speculators who desired to bear the risk of unpredictable market movements but not of unpredictable margin calls. Since the latter risk depends on the former, however, this advantage seems of little economic or predictive value.

40. A mechanical system, which could not be adjusted or manipulated to achicie some flexibility when brokers felt that market conditions were only momentarily out of balance, would be unattractive to brokers and clients alike. Large investors would probably prefer a system without standards that allowed them to use their economic power to bargain for various credit privileges. Such a desire on the part of major customers might push brokers into competition against each other to offer the most amorphous and manipulable margin systems. 
standards for making margin maintenance calls. The net effect of Rule 10b-16's disclosure requirements will thus probably be to encourage the adoption of the least informative and most arbitrary systems.

Even if Rule 10b-16 prompted some meaningful disclosure, however, the Rule would still be inconsistent and irrational, since gaps in its coverage cause customers in essentially similar transactions to be protected in rather dissimilar ways. The Rule, for example, only applies to broker-dealers and does not reach banks or other lenders who sometimes extend margin credit. ${ }^{41}$ As a result, an investor could borrow against securities from a broker and be covered by Rule 10b-16, yet borrow the same amount, pledging stock, from a bank and be covered by the Truth in Lending Act. ${ }^{2}$ In another instance, distinguishable only by the increased size of the transaction, a loan from a broker would be covered by the Rule, but the same loan from a bank would be beyond the jurisdiction of the Act. ${ }^{43}$ Functionally equivalent transactions would thus receive different treatment.

Differences in the transactions covered by Rule and Act also undermine the congressional purpose of protecting small investors. Congress exempted transactions exceeding $\$ 25,000$ from the provisions of the Truth in Lending Act and thus indicated an intention to protect the relatively disadvantaged and to let the wealthy and financially sophisticated take care of themselves. ${ }^{44}$ The consequences of the Rule's disclosure scheme, however, point in a very different direction. The absence of an exemption for large transactions in Rule 10b-16 creates incentives that undermine the disclosure scheme, because, to the extent

41. See 17 C.F.R. $\$ 240.10$ b-16 (1976) (Rule applies only to brokers or dealers). This is, of course, a direct result of the bifurcation introduced by the Act. See 15 U.S.C. $\$ 1603(2)$ (1970). Previously existing federal regulation of margin in the securities markets, by contrast, dealt with both broker-dealers and banks and treated them approximately the same. See 12 C.F.R. $\$ \$ 220$ (Regulation T), 221 (Regulation U) (1976). There were some gaps even in this system, however. Lenders other than brokers, dealers, or banks (e.g., individuals or small-loan companies) were not subject to regulation. See 2 L. Loss, supra note 5, at 1256.57 (2d ed. 1961). Also unregulated were loans made for another purpose, such as a mortgage, which allowed investors to use funds for stock speculation that would otherwise be tied up in property or other uses. Cf. 5 L. Loss, supra note 5, at 3275-76 (2d ed. 1961) (giving examples of how banks may extend credit on any collateral other than "stock" for purpose of carrying securities of any kind).

42. Bank loans in amounts less than $\$ 25,000$ come under the jurisdiction of the Act. See 15 U.S.C. $\$ 1603(3)$, (5) (1970 \& Supp. V 1975). But Rule 10b-16 covers only margin loans extended by brokers or dealers. See 17 C.F.R. $\$ 240.10 b-16$ (1976). No mention is made of banks, which are specifically excluded from the definition of the terms "broker" and "dealer" in the $193 \frac{1}{4}$ Act. See 15 U.S.C. $\$ 78(c)(4),(5)(1970)$.

43. For example, a $\$ 100,000$ margin loan by a broker would be covered by the disclosure requirements of the Rule; the same loan by a bank would be outside the jurisdiction of Truth in Lending. Compare 15 U.S.C. $\$ 1603(3)(1970)(\$ 25,000$ limit on coverage) wilh 17 C.F.R. $\$ 240.10$ b-16(a) (1976) (no limit on transaction size).

44. See p. 374 \& notes $10-14$ supra. 
that brokerage houses are exposed to huge Rule 10b-16 liabilities in dealing with their larger customers, ${ }^{45}$ there are incentives for them to get out of the business of making margin loans and to steer their clients toward lenders not covered by the Rule. ${ }^{46}$ Small as well as large investors would be forced to borrow from banks, which would not be covered by the special margin disclosure requirements of the Rule. ${ }^{47}$ Furthermore, those brokers who continued to provide margin credit would be forced to increase their charges to cover the cost of insuring against the possibility of huge liability. These added costs and inefficiencies imposed on the margin system would certainly be a far cry from what Congress contemplated when it mandated a margin disclosure rule.

\section{B. Remedies}

The SEC may bring suits to enjoin violations of the Securities Exchange Act of $1934 . .^{48}$ In addition, courts have recognized an implied

45. Potential liability could be very large, depending on external factors such as size of account and performance of the market rather than extent or seriousness of violation. See p. 393 \& notes $79-81$ infra.

46. In the past, when margin trading was rendered unattractive by high initial margins, customers have turned to unregulated lenders for funds. See 2 L. Loss, supra note 5, at 1257 (2d ed. 1961) (referring to such activities when margins were at $100 \%$ in 1946); Moore, How Trader's Beat the 70\% Margin, Bus. WeEk, April 8, 1967, at 51 (describing more recent practices).

47. It is possible that shifting more margin loans to banks would raise the cost of credit for margin customers. First, interest rates on such loans might well be higher. Competitive brokerage houses currently offer their large customers rates slightly below the prime rate, see note 28 supra; it is doubtful that banks would want to be so generous. Indeed, they would not make margin loans until the return on them was as great as the return on other short-term business loans. Second, internal bank policies may preclude the commitment of more than a certain percentage of bank assets to margin loans. If brokers are no longer willing to make margin loans, the amount of funds available for these loans will decline. As a result, the cost of margin loans will probably rise as a means of apportioning the smaller amount of available money among potential margin clients. Moreover, bank policy may require more collateral and more rapid margin calls than current brokerage house practice. These factors could push margin customers away from banks and toward other nonbroker lenders, who might be even more expensive. The switch to banks and on to other lenders could thus generate added costs and inefficiencies not contemplated by the lawmakers and hence is without a clear justification. Margin could be made less attractive and thus could be curtailed as a speculative tool by the operation of Rule 10b-16.

48. 15 U.S.C. $\$ 78 u(e)(1970$.) The agency can also seek criminal sanctions. See generally 3 A. Bromberg, supra note $5, \$ 10.1$, at $234-35,427-28 ; 3 \mathrm{~L}$. Loss, supra note 5 , at 1975 83 (2d ed. 1961); 6 id. at 4108-23 (2d ed. Supp. 1969). In addition, the SEC can use "threats of prosecution or proceedings, or the promise of light sanctions, or other forms of negotiation, to obtain restitution for defrauded individuals." 3 A. Bromberg, supra note 5 , $\$ 10.2(1)$, at 237 . Alternatively, the agency can go to court directly in aid of individuals seeking private relief. See id. $\$ 10.2(2)$, at $236-39,428 ; 3$ L. Loss, supra note 5, at 1824-29 (2d ed. 1961); 6 id. at 3970-77 (2d ed. Supp. 1969). The 1934 Act also provides for express private rights of action. 15 U.S.C. $\$ 78 \mathrm{i}$ (1970) (\$ 9 prohibition against manipulation of securities registered on exchanges); id. $\S 78 \mathrm{p}(\mathrm{b})(1970)(\S 16(\mathrm{~b})$ recovery 
private right of action under section $10(\mathrm{~b}) .^{49}$ Rule $10 \mathrm{~b}-16$ can probably be enforced by either of these means.

SEC injunctive suits brought under the Rule could be a useful means of redress for certain nondisclosure violations with regard to margin accounts..$^{50}$ Indeed, given the Rule's nature as a securities law regulation, such suits would be the only relief available where brokerdealers had violated the margin restrictions but had not caused their customers easily identifiable or measurable economic harm that could be rectified in a private suit. ${ }^{51}$ Even where individual plaintiffs could seek money damages, injunctive relief obtained by the SEC would ensure benefits to the public as a whole through court-ordered changes in margin information forms or disclosure procedures.

Injunctive relief, however, has limited value for margin account holders. The potential of SEC suits to enjoin compliance with Rule $10 \mathrm{~b}-16$ is circumscribed by the nature of the violations, practical and legal limits on the agency's enforcement powers, and policy considerations. Unlike certain other securities violations, such as stock manipulation or insider trading, margin nondisclosures are difficult to police because often there is no external manifestation of the wrong. ${ }^{52}$ For

by isster of insiders' short-term trading profits); $i d . \$ 78 \mathrm{r}(1970)$ ( $\$ 18$ liability for misleading statements filed with the SEC). See 2 L. Loss, supra note 5, at 1040-90 (2d ed. 1961); 3 id. at 1746-54; 5 id. at 3003-50 (2d ed. Supp. 1969); 6 id. at 3860-63.

49. Supcrintendent of Ins. v. Bankers Life \& Cas. Co., 404 U.S. 6 (1971) (Rule 10b-5); Kardon v. National Gypsum Co., 69 F. Supp. 512 (E.D. Pa. 1946). Courts have implied a private right of action for other sections of the 1934 Act that do not specifically authorize one. See, e.g., J. I. Case Co. v. Borak, 377 U.S. 426 (1964) (\$ 14(e), 15 U.S.C. $\$ 78 n(e)(1970)$; prohibition of fraud in tender offers); Pearlstein v. Scudder \& German, 429 F.2d 1136 (2d Cir. 1970), cert. denied, 401 U.S. 1013 (1974) (\$ 7 , 15 U.S.C. $\$ 78 \mathrm{~g}(1970)$; margin regulation); 3 L. Loss, supra note 5, at 1757-97 (2d ed. 1961); 6 id., at 3865-3925 (2d ed. Supp. 1969); Comment, Tender Offers: An Analysis of the Early Development of Standing to Sue Under Section $1 f(e), 5$ TExas Tech. L. Rev. 779 (1974).

50. Possible Rule $10 \mathrm{~b}-16$ violations can be divided into three basic categories: (1) nondisclosure of some material aspect of the prospective credit transaction; (2) erroneous disclosure, by accident or design, of some fact or figure, such as the interest rate; (3) inadequate disclosure of a general policy with regard to margin maintenance calls, as in Liang. SEC power to bring suit theoretically would apply to each situation.

51. Such a situation could arise in several ways. Disclosure of credit terms could be so unsatisfactory as to deter a customer from opening or trading in a margin account. Or, because of a favorable market, nondisclosures could mislead margin consumers without causing them any discernible economic harm. Finally, violations might be harmful but nonetheless unredressable because the plaintiff might well be unable to satisfy the increasingly stringent requirements of a securities law cause of action. See pp. 388-90 infra.

52. Unexplained price changes and sudden increases in trading volume help alert the Commission to possible violations of $\$ 9$ or $\$ 10(\mathrm{~b})$ of the Securities Exchange Act. Changes in insider stock holdings, as indicated by forms filed with the agency, are evidence of $\$ 16$ (b) trading. In addition, information passed on to the government by disgruntled employees or partners may provide the basis for investigation of possible violations. For $10 \mathrm{~b}-16$ violations, particularly margin call nondisclosures, however, an SEC investigation would yield sparse results. Indications of violations of the Rule, far from manifesting themselves in market behavior, would not even appear in an examination of a brokerage 
instance, the paradigmatic Rule $10 \mathrm{~b}-16$ violation, failure to disclose margin call standards, can be detected only by observing the circumstances under which such calls are made; and individual plaintiffs would be in a much better position than the SEC to evaluate whether margin calls were made on the basis of the disclosed standards. Yet even if the securities agency could develop an effective policing system, lack of manpower suggests that many violations would go unnoticed and unpunished. ${ }^{53}$ Since agency enforcement is normally for the financially unsophisticated, ${ }^{5 *}$ margin account holders should be regarded as at best secondary objects of agency concern. ${ }^{55}$ Finally, the

firm's financial records or statements of customers' accounts. The fact that the firm failed to follow the margin call standards disclosed to customers, for instance, would not be apparent from a review of the firm's records. Only where brokers had not "established procedures to assure that each customer" was given the information required in the Rulc would the violation be easily discoverable. There would presumably be few violations of this type.

53. Inadequate manpowcr for the policing and enforcement of the securities law has long been a problem for the SEC. The need for a "supplement to Commission action" in a field where the SEC was understaffed was one of the factors inducing the Supreme Court to approve a private right of action under the proxy rules of the 1934 Act. See J.I. Case Co. v. Borak, 377 U.S. 426, 432 (1961). As recently as March 1976, the SEC was citing lack of personnel as a reason the Court should grant standing to a disappointed tender offeror under $\$ 14(\mathrm{e})$ of the $1934 \mathrm{Act}$, $15 \mathrm{U}$.S.C. $\S 78 \mathrm{n}(\mathrm{e})(1970)$, an antifraud section applying to mergers but quite similar to $\$ 10(\mathrm{~b})$. See Piper v. Chris-Craft Indus., Inc., 430 U.S. 1, 24-26, 41-42, 64-65 (1977). This paucity of enforcement resources is a particular problem in policing the margin regulations of the $1934 \mathrm{Act}$, so that private rights of action thus play a significant role in $\$ 7$ litigation. See V. BRUdNEY \& M. Chirelstein, Cases and Materials on Corporate Iinance 354 (1972). If the SEC lacks the manpower necessary for the enforcement of major sections and rules of the $1934 \mathrm{Act}$, it would have even fewer resources to devote to detection of violations of the rules it perceives as less important or more limited in scope.

54. This is the assumption of the Truth in Lending Act. See 1967 House RErorT, supra note 2, at 18. Courts interpreting the statute have agreed. See, e.g., Ratner v. Chemical Bank New York Trust Co., 309 F. Supp. 983, 987 (S.D.N.Y. 1970). Thus, it has been stated repeatedly that Congress established the disclosure provisions of the various securities acts expressly to protect small or gullible investors. See, e.g., Surowitz v. Hilton Hotels Corp., 342 F.2d 596, 602 (7th Cir. 1965), rev'd on other grounds, 383 U.S. 363 (1966) (policy of federal securities laws to protect uninformed, ignorant, and gullible investors); Dolgow v. Anderson, 43 F.R.D. 472,482 (E.D.N.Y. 1968) (disclosure provisions of securities laws designed to protect small investors). See also SEC, SumMarY of Disclosure Policy Study Report (Wheat RePort), [1963-1972 Special Studies Transfer Binder] Frd. SEC. L. REP. (CCH) $\{74,603$, at 65,241 (1969) (primary purpose of congressional disclosure policy to provide investors with "enough information to enable them to arrive at their own rational decisions"). As the agency charged with the enforcement of the securities laws, the SEC has often urged safeguards for "unsophisticated investors." S. REP. No. 1775, 76th Cong., 3d Sess. 21 (1940) (discussing the Investment Advisers Act of 1940). Cf. SEC v. Capital Gains Research Bureau, Inc., 375 U.S. 180, 187-89 (1963) (discussing SEC's study of investment trusts and companies which led to $1940 \mathrm{Act}$ ). See Levenson, The Role of the SEC as a Consumer Protection Agency, 27 Bus. LAw. 61 (1971).

55. This is perhaps an ancillary reason why no SEC actions have yet been prosecuted. If the agency felt that margin customers did not really need protection or could better look after their own interests through private suits, it would have an added incentive to make Rule 10b-16 violations a low-priority enforcement item. Small margin investors, 
effectiveness of SEC protection of margin customers will be diminished by judicially imposed restrictions on Commission lawsuits. ${ }^{j o}$ This perhaps explains why no SEG injunctive suits under the Rule have as yet been brought.

Given the limitations of SEC injunctive suits, private actions will probably be the primary method of enforcing Rule $10 \mathrm{~b}-16 .{ }^{57}$ Indeed, a private right of action is essential if economic damages flowing from margin violations in connection with the purchase or sale of securities are to be redressed. The benefits available to investors from such private actions, however, are limited both by the elements that must be proved to establish a cause of action and by the measure of damages recoverable in a successful suit. The result is a scheme of regulation that is both irrational in its operation and inconsistent with the consumer protection intent that Congress manifested in the Truth in Lending Act. 58

however, may still be perceived to require the benefits of scaled-down enforcement of Rule $10 \mathrm{~b}-16$ more than wealthy and knowledgeable margin speculators. See p. 375 \& note 18 supra.

56. The SEC has been required in an injunctive suit to establish scienter on the part of the defendant and to show that the alleged violations would be repeated. See SEC v. Bausch \& Lomb, Inc., 420 F. Supp. 1226 (S.D.N.Y. 1976). This requirement, which appears to flow from the language of Ernst \& Ernst v. Hochfelder, 425 U.S. 185 (1976), would make SEC suits more difficult to prosecute successfully. See Berner \& Franklin, Scienter and Securities and Exchange Commission Rule 10b-5 Injunctive Actions: A Reappraisal in Light of Hochfelder, 51 N.Y.U.L. REv. 769 (1976). Proving scienter would probably be particularly difficult in a $10 \mathrm{~b}-16$ injunctive suit, since a violation would hardly ever arise except in cases of brokerage house ignorance or negligence. Defendants would seldom act with scienter, because there is usually little to gain from misrepresentation.

57. Courts have allowed plaintiffs to maintain private rights of action for violations of SEC Rules 10b-5 and 10b-6. See note 49 supra (Rule 10b-5); Piper v. Chris-Craft Indus., Inc., 430 U.S. 1 (1977) (Rule 10b-6); $c f$. id. (intimating private right under Rule 10b-13). The argument that private damage actions are cognizable under Rule $10 \mathrm{~b}-16$ is further supported by the Supreme Court's holding that causes of action for violations of Rule $10 \mathrm{~b}-5$ arise under $\$ 10(\mathrm{~b})$ and not under the Commission's Rule. See Ernst \& Ernst v. Hochfelder, 425 U.S. 185, 213-14 (1976) (scope of Rule 10b-5 “cannot exceed the power granted the Commission by Congress under $\$ 10(\mathrm{~b}) ")$.

The Liang court, in discussing a possible recovery under Rule 10b-16, stated: "It may safely be assumed that noncompliance with Rule $10 \mathrm{~b}-16$ provides the basis for a private cause of action. It is already established that a violation of Rule $10 \mathrm{~b}-5$, a rule of disclosure analogous to Rule 10b-16, implies a civil remedy." 540 F.2d at 1113 n.25. The right of plaintiff to sue was not questioned in the only other case to interpret $10 \mathrm{~b}-16$, Stephens v. Reynolds Sec., Inc., 413 F. Supp. 50 (N.D. Ala. 1976).

In implying a private right of action under the margin regulations of $\$ 7$ of the 1934 Act, 15 U.S.C. $\$ 78 \mathrm{~g}(1970)$, the Second Circuit stressed the importance of private actions to the regulatory scheme: "the danger of permitting a windfall to an unscrupulous investor is outweighed by the salutary policing effect which the threat of private suits for compensatory damages can have upon brokers and dealers above and beyond the threats of governmental action by the Securities and Exchange Commission." Pcarlstein v. Scudder \& German, 429 F.2d 1136, 1141 (21 Cir. 1970), cert. denied, 401 U.S. 1013 (1974).

58. It could be argued that if the Rule's private enforcement leads to irrational results, the Rule should be construcd as not having a private damage remedy, since 
The threshold element necessary to establish an implied private cause of action under Rule 10b-16 is standing. Section 10(b) differs from other sections of the 1934 Act dealing with violations for which private remedies have been implied in that it speaks specifically of fraudulent practices "in connection with the purchase or sale of securities." Courts have thus held that plaintiffs who bring private damage actions under section 10 (b) must be purchasers or sellers of securities. ${ }^{60}$ The language of Rule 10b-16 itself also suggests that plaintiffs must be purchasers or sellers of securities because of the Rule's prohibition of nondisclosure violations "in connection with any securities transaction." "1

several of the other $\$ 10(b)$ rules are enforced only through SEC action. One of the reasons Rule $10 \mathrm{~b}-16$ appeared as a $\$ 10(\mathrm{~b})$ rather than a $\S 15(\mathrm{c})$ rule of the 1934 Act was because the Commission planned for margin investors to be able to rely on the private right of action afforded by $\$ 10(\mathrm{~b})$. See Interviews, supra note 27. Moreover, given the problems of SEC enforcement, see pp. 385-87 \& notes 52-56 supra, absence of a private right of action in Rule 10b-16 would leave the protected class of margin investors with hardly any protection at all.

59. 15 U.S.C. $\$ 78 \mathrm{j}(\mathrm{b})(1970)(\$ 10(\mathrm{~b}))$. Compare id. with $\$ 14(\mathrm{e})$, id. $\$ 78 \mathrm{n}(\mathrm{c})$ (forbidding fraudulent and manipulative practices "in connection with any tender offer or request or invitation for tenders, or any solicitation of security holders in opposition to or in favor of any such offer, request, or invitation"). It is generally agreed that the language of $\$ 14(\mathrm{e})$ eliminates the Birnbaum sale-purchase limitation, see Birnbaum v. Newport Steel Corp., 193 F.2d 461 (2d Cir.), cert. denied, 343 U.S. 956 (1952), and broadens standing to bring suit under the Securities Exchange Act. See, e.g., Smallwood v. Pearl Brewing Co., 489 F.2d 579, 596 (5th Cir.), cert. denied, 419 U.S. 873 (1974); Electronic Specialty Co. v. International Controls Corp., 409 F.2d 937, 916 (2d Cir. 1969); McCloskey v. Epko Shoes, Inc., 391 F. Supp. 1279, $1281-82$ (E.D. Pa. 1975); 1 A. BromberG, supra notc $5, \S 6.3(1010)$, at 122.16-.17.

60. See Blue Chip Stamps v. Manor Drug Stores, 421 U.S. 723 (1975); Birnbaum v. Newport Steel Corp., 193 F.2d 461 (2d Cir.), cert. denied, 343 U.S. 956 (1952). See generally 2 A. BromberG, supra note $5, \S 8.8$, at $221-22.1 ; 3$ id. $\$ 8.8$, at $423-24.5$; 3 L. Loss, supra note 5 , at $1472-73$ (2d ed. 1961); 6 id. at $3644-46$ (2d ed. Supp. 1969). In reaffirming the Birnbaum rule, the Blue Chip Court listed among its reasons for accepting the purchaser-seller requirement the following "policy" considerations: the possibility of vexatious litigation in the absence of such a rule, the danger that suits would deal with hazy factual issues relating to whether or not a plaintiff would have purchased or sold the stock, and the problem that proof would depend on uncorroborated oral testimony. 421 U.S. at 737-49. These policies are also applicable to private actions for violations of Rule 10b-16.

61. 17 C.F.R. $\$ 240.10$ b-16(a) (1976). Such a standing limitation would probably not hinder most aggrieved margin customers, who would have bought or sold securities in their account during the period of nondisclosure. Yet Rule $10 \mathrm{~b}-16$ standing would be denied in cases of a violation without a corresponding purchase or forced sale. See, e.g., note 50 supra. Other examples could include nondisclosure violation arising in a margin account opened with the deposit or transfer of stock already owned by the client, rather than by a purchase or sale of new stock; or a margin call made pursuant to an improperly disclosed margin system which was met by a cash transfer rather than by a forced sale of collateral. Although it could be argued that any of these various events would represent a "securities transaction" within the meaning of Rule 10b-16, the question is far from clear.

Even if these events could satisfy the "securities transaction" language of the Rulc, moreover, they would still have to hurdle the "purchase or sale" language of $\$ 10(\mathrm{~b})$. Ernst \& Ernst v. Hochfelder, 425 U.S. 185, 213-14 (1976), held that causes of action arise under $\S 10(\mathrm{~b})$ and not Rule $10 \mathrm{~b}-5$, and that a Rule's "scope cannot exceed the power granted 
The "purchase or sale" standing requirement of section $10(\mathrm{~b})$ is considerably stricter than the analogous provision of the Truth in Lending Act, which allows recoveries for damages suffered "in connection with any consumer credit transaction." 62 Thus although under the Act a plaintiff can recover for any nondisclosure of credit terms merely upon proof of the violation, a similar nondisclosure under the Rule is actionable only if accompanied by the purchase or sale of a security. To prove a section 10 (b) violation the plaintiff must also show that the alleged Rule 10b-16 nondisclosure involved material margin information, ${ }^{63}$ induced reliance on his part, ${ }^{64}$ caused the harm com-

the Commission by Congress under $\$ 10(b)$." The conclusion that the purchase or sale requirement is applicable to Rule $10 \mathrm{~b}-16$ is further supported by cases decided before Hochfelder that had considered standing under the other $\$ 10(\mathrm{~b})$ rules. See Bache \& Co. v. International Controls Corp., 324 F. Supp. 998 (S.D.N.Y. 1971), 339 F. Supp. 341 (S.D.N.X.), aff'd, 469 F.2d 696 (2d Cir. 1972) (Rule 10b-4 violation raised as defense); Weitzen v. Kearns, 271 F. Supp. 616 (S.D.N.Y. 1967) (Rule 10b-6); Miller v. Steinbach, 268 F. Supp. 255 (S.D.N.Y. 1967) (Rule 10b-6); SEC v. Scott Taylor \& Co., 183 F. Supp. 904 (S.D.N.Y. 1959) (Rule 10b-6). But see Chris-Craft Indus., Inc. v. Piper Aircraft Corp., 480 F.2d 341, 378 \& n.32 (2d Cir. 1973), rev'd on other grounds sub nom. Piper v. Chris-Craft Indus., Inc., 430 U.S. 1 (1977).

62. 15 U.S.C. $\$ 1640(a)(1970)$. This language was broadened in 1974 to read: "any creditor who fails to comply with any requirement imposed under this part ... with respect to any person is liable to such person." 15 U.S.C. $\$ 1640$ (a) (Supp. V 1975).

The requirement that the plaintiff demonstrate a connection between the defendant, or his actions, and the challenged consumer credit transaction has not proved onerous. See, e.g., Ljepava v. M.L.S.C. Properties, Inc., 511 F.2d 935 (9th Cir. 1975) (separate promisees under mortgage loan could be held individually liable); Manning v. Princeton Consumer Discount Co., Inc., 390 F. Supp. 320 (E.D. Pa. 1975), aff'd, 533 F.2d 102 (3d Cir. 1976) (automobile dealer arranging credit, not loan company, liable for nondisclosures); Childress v. Mobile Living Corp., 386 F. Supp. 903 (E.D. La. 1974), aff'd mem., 525 F.2d 1406 (5th Cir. 1976) (one arranging for the extension of credit to consumer and receiving from another party fee therefor could be liable for nondisclosures); Ratner v. Chem. Bank N.Y. Trust Co., 329 F. Supp. 270 (S.D.N.Y. 1971) (creditor liable to plaintiff for failure to disclose annual interest rate on monthly statement, even though no finance charges had yet been incurred).

63. See generally 2 A. Bromberg, supra note $5, \S 8.3$, at $199-202 ; 3$ id. $\$ 8.3$ at 419.20 . The Supreme Court's most recent formulation of the materiality test requires a showing of a "substantial likelihood that, under all the circumstances, the omitted fact would have assumed actual significance in the deliberations" of reasonable shareholders. TSC Indus., Inc. v. Northway, Inc., 426 U.S. 438,449 (1976). Earlier tests of materiality required only that the nondisclosures might have been important in influencing plaintiffs' actions. See, e.g., Affiliated Ute Citizens v. United States, 406 U.S. 128, 154 (1972); Mills v. Electric Auto-Lite Co., 396 U.S. 375, 389 (1970). Hence, although materiality standards might be easier to meet given the direct personal interaction between margin account broker and customer, see 2 A. Bromberg, supra note $5, \$ 8.3$, at 199 , potential Rule $10 \mathrm{~b}-16$ plaintiffs may still encounter difficulties.

64. See generally 2 A. BRomberg, supra note 5 , $\$ 8.6$, at $209-12 ; 3$ id. $\$ 8.6$, at 420.7 . 421; 3 L. Loss, supra note 5, at 1765-66 (2d ed. 1961); 6 id. at 3876-90 (2d ed. Supp. 1969); Note, The Reliance Requirement in Private Actions under SEC Rule 10b-5, 88 HARv. L. REv. 584 (1975). Reliance is particularly difficult to establish in Rule 10b-5 actions, especially since a plaintiff claiming nondisclosure violations must prove that he believed the opposite facts to be true and acted upon this misconception. See List v. Fashion Park, Inc., 340 F.2d 457, 462 (2d Cir.), cert. denied, 382 U.S. 811 (1965). Hence, the Supreme Court has held that "positive proof" of reliance is not essential if plaintiff establishes the materiality of the alleged nondisclosure. See Affiliated Ute Citizens v. United States, 406 U.S. 128, 153-54 (1972). 
plained of, ${ }^{65}$ and occurred with scienter on the part of the defendant. ${ }^{.66}$ Because a plaintiff must establish these five elements for a successful Rule 10b-16 cause of action, private damage suits under the Rule provide considerably less protection to margin account holders than the parent Truth in Lending Act provides to other credit customers. For instance, although the Rule's "purchase or sale" standing requirement would probably be deemed satisfied by the initial purchase in the account whose terms were the subject of a nondisclosure violation, ${ }^{67}$ or by the forced sale due to inability to meet an improperly disclosed margin call, ${ }^{68}$ not all courts would necessarily reach this

65. See generally 2 A. Bromberc, supra note 5 , $\$ 8.7$, at $213-20 ; 3$ id. $\$ 8.7$, at $421-23$; 6 L. Loss, supra note 5, at $3880-83$ (2d ed. Supp. 1969). Since very few cases have dealt with the question, Rule $10 \mathrm{~b}-5$ causation law is still somewhat unclear. Nonetheless, existing cases require a showing of some causal connection between the misconduct alleged and the economic loss suffered. See, e.g., Affiliated Ute Citizens v. United States, 406 U.S. 128, 154 (1972) (requiring causation in fact); cf. Mills v. Electric Auto-Lite Co., 396 U.S. 375, $385(1970)$ (if materiality established, requisite causation proved if misleading proxy statement was "an essential link in the accomplishment of the transaction"). Exceptions to the causation requirement are usually based on grounds of public policy. See Weber v. Bartle, 272 F. Supp. 201, 204 (S.D.N.Y. 1967).

Whatever the rigor of the judicial standards, margin customers would frequently have difficulty proving that the nondisclosure caused their harm. In the case of a forced sale, the margin call would be caused by a decline in the value of the stocks held on margin, not by nondisclosure of the standards for making the call. Even if some courts were to accept nondisclosure as an indirect cause, plaintiffs would often lose on this issue, since some judges have stated quite explicitly that the securities laws are not a system of investors' insurance. See, e.g., List v. Fashion Park, Inc., 340 F.2d 457, 463 (2d Cir.), cert. denied, 382 U.S. 811 (1965); Barnett v. Anaconda Co., 238 F. Supp. 766, 770 (S.D.N.Y. 1965). For a discussion of the kind of causation required in a $10 \mathrm{~b}-16$ private action dealing with the additional collateral requirement, see 51 N.Y.U. L. REv. 1050, 1075-76. The author suggests that a plaintiff could allege causation by asserting that "had he known of defendant's collateral policies (I) he would have found another broker-dealer who would not have called for collateral when the defendant did; or (2) he would not have purchased stock on margin at all." $I d$. at 1075. It is even less clear what kind of allegations would be required in a claim for damages based on a nondisclosure of the proper interest rate, although allegations similar to those outlined above would usually suffice to establish a cause of action. Proof, of course, is a different matter.

66. In Ernst \& Ernst v. Hochfelder, 425 U.S. 185 (1976), the Supreme Court held that $\S 10(b)$ civil liability arises only upon proof that the defendant acted with scienter, generally in Rule $10 \mathrm{~b}-5$ an intent to deceive, manipulate, or defraud. See generally $2 \mathrm{~A}$. Bromberg, supra note 5, $\$ 8.4(000)-(120)$, (500)-(659), at 203-204.1, 204.101-.258; 3 id. $\$ 8.4$ (500), at 420-420.7; 3 L. Loss, supra note 5, at 1766 (2d ed. 1961); 6 id. at 3883-88 (2d ed. Supp. 1961). Scienter may be difficult for margin customers to prove. Many brokerage firms will have revised their margin agreements to comply, at least facially, with the new requirements of Rule 10b-16. Demonstration that such revisions were made with an intent to deceive, or that the presentation of such forms to new customers was an intentionally deceptive act, would probably not be easy.

67. The acquisition of a security in the marketplace would obviously qualify as a "purchase" under $\$ 10(\mathrm{~b})$ of the $1934 \mathrm{Act}$, and if the nondisclosure occurred "in connection" with the purchase, a $\$ 10(\mathrm{~b})$ cause of action could be alleged. See note 59 supra. Of course, until a sale occurred, there would be no measurable economic loss.

68. This represents the third type of Rule $10 \mathrm{~b}-16$ violation described in note 50 supra. As is demonstrated by the Liang case, customers who failed to meet a margin call in a falling market, provoking a sale of securities from their account, could sue under the Rule. Yet, it is hard to see how the other two types of violations could consistently be 
conclusion. Even if standing to bring suit were established, plaintiffs would find it difficult to meet the other requirements of a section 10 (b) cause of action, either because courts have construed these elements against plaintiffs with increasing severity ${ }^{69}$ or because of evidentiary problems peculiar to the Rule. ${ }^{70}$ The prospect of relief held out by a private Rule $10 \mathrm{~b}-16$ suit may well prove illusory.

This dissimilarity between the protection offered by the Truth in Lending Act and Rule 10b-16 might be explained as evidence of a congressional intent to provide fewer safeguards for margin customers because they are sophisticated investors. ${ }^{71}$ Yet by conditioning recovery on the fortuity of a purchase and sale accompanying a nondisclosure, the Rule fails to scale down protection of this group in any rational way. If the current disclosure provisions of the Rule were violated in the absence of a corresponding securities transaction, for example, the section 10 (b) standing requirement would not be satisfied. Furthermore, plaintiffs' frequent inability to meet the other requirements of a Rule 10b-16 suit introduces even greater disparities in protection, since it means that most $10 \mathrm{~b}-16$ violations are not redressable by private parties. ${ }^{22}$ Thus, unlike Truth in Lending's automatic recovery

actionable. A misstatement or nondisclosure of the interest rate would not occasion a forced sale through the mechanism of a margin call, and other nondisclosures might not either. The only one of these situations clearly actionable under the Rule would be where a customer was induced to open and trade in an account by the seeming attractiveness of misrepresented credit terms. But such a violation would also be a Rule 10b-5 infraction. See p. 395 \& notes 88-90 infra.

69. Defendants before the Supreme Court have prevailed with increasing frequency in actions brought under the 1934 Act. See, e.g., Piper v. Chris-Craft Indus., Inc., 430 U.S. 1 (1977) (\$ 14(e)); TSC Indus., Inc. v. Northway, Inc., 426 U.S. 438 (1976) (\$ 14(a)); Ernst \& Ernst v. Hochfelder, 425 U.S. 185 (1976) (\$ 10(b)); Foremost-MIKesson v. Provident Sec. Co., 423 U.S. 292 (1976) (\$ 16(b)); Blue Chip Stamps v. Manor Drug Stores, 421 U.S. 723 (1975) (\$ 10(b)); Kern County Land Co. v. Occidental Petroleum Corp., 411 U.S. 582 $(1973)$ (\$ 16(b)); notes $62,63 \& 66$ supra.

70. See notes 62-66 supra. Proof problems involved with materiality, reliance, causation, and scienter are examined in 51 N.Y.U.L. REv. 1050, 1066-76. The author there concludes that "[p]roving scienter and causation may be particularly difficult for the rule 10b-16 plaintiff." Id. at 1079 .

71. If this is Congress's intent, it is ill-expressed and does not fit well with the other evidence. See pp. 374-76 \& notes 15-22 supra. Indications are that the legislators wanted margin customers to receive protection similar to that afforded other consumers by Truth in Lending, qualificd only by the SEC's determination of the specific type of information that needed to be disclosed to margin investors. See pp. 377-78 \& note 27 supra. It is doubtful that the different recovery standards of Act and Rule were considered by the Congress; certainly it did not expressly sanction a lesser measure of protection for margin account holders.

72. In this respect, the Rule fails to accomplish the intent of its drafters at the SEC, who believed that promulgation of Rule $10 \mathrm{~b}-16$ as a $\$ 10$ (b) rule would allow vigorous private enforcement of the disclosure requirements. See Interviews, supra note 27. Such a belicf was not surprising in 1968, when $\$ 10(\mathrm{~b})$ was expanding as a tool of securities law enforcement. However, the ascendancy of restrictive interpretations of the various clements of a $\$ 10(\mathrm{~b})$ cause of action seriously impairs Rule 10b-16's ability to function as an individual investor protection measure. 
system, Rule 10b-16's securities law structure creates a situation in which violations of the Rule rarely produce damage arvards for aggrieved margin customers.

The inadequacy of the remedies offered by Rule $10 \mathrm{~b}-16$ is compounded by the absence of a broadly applicable damage formula for violations of the Rule. No court has considered the measure of damages in a Rule $10 \mathrm{~b}-16$ private suit. ${ }^{73}$ It is likely that courts would adopt a measure of damages ${ }^{74}$ similar to that in other section $10(\mathrm{~b})$ actions. ${ }^{75}$ This damage formula is inconsistent with that of the Truth in Lending Act. Under the Act, damages are limited and are automatic when a credit nondisclosure violation occurs. ${ }^{76}$ Under a section $10(\mathrm{~b})$ cause of action, damages are not in any way fixed but depend rather on the showing of economic harm caused by the violation. ${ }^{i 7}$ If the damage measure urged by the plaintiffs in Liang were adopted, recovery would

73. The Liang court remanded for a determination, inter alia, of "what recovery, if any, is appropriate for any noncompliance with [the] Rule." 540 F.2d at 1113 (footnotes omitted).

74. A court would have several choices. Private damage awards could be based on the interest charges in the transaction, as in the Truth in Lending Act. See 15 U.S.C. $\$ 1640$ (a)(2)(A) (Supp. V 1975). Another possibility would be the type of recovery sought in the Liang case, the difference between the price the securities brought upon forced sale and the amount for which they could have been sold "within a reasonable time thereafter." 540 F.2d at 1110 . This resembles one of the usual $\S 10(b)$ recovery formulas. See note 77 infra. Finally, there could be no private damages at all. The Liang court raised this specter when it spoke of a 10b-16 "recovery, if any." 540 F.2d at 1113 (emphasis added).

75. This is so not only because of the existence of $\$ 10(\mathrm{~b})$ damage formulas, see note i7 infra, but also because of the unsatisfactory nature of alternative damage standards. Awards linked to interest charges are in no way suggested by the language or case law of the 1934 Act, or by the general terms of the Rule. Not awarding damages at all, the other possibility, would render the private right of action virtually useless.

76. See 15 U.S.C. $\$ 1640$ (a) (Supp.V 1975); note 12 supra.

77. As Professors Bromberg and Loss point out, there is little decisional law on proper damage standards under $\$ 10(\mathrm{~b})$ because few Rule $10 \mathrm{~b}-5$ cases reach the relief stage. $3 \mathrm{~A}$. BromberG, supra note 5, $\$ 9.1$, at 225; 3 L. Loss, supra note 5, at 1792-93 (2d ed. 1961). However, "[d] efrauded buyers who have prevailed on the merits have typically recovered their purchase price on a rescission measure of damages. . . Prevailing defrauded sellers have done better by virtue of a constructive-trust approach, which gives them whatever profits the buyer has garnered on resale." $3 \mathrm{~A}$. Bromberg, supra note $5, \$ 9.1$, at 226-2 7 . Another measure for sellers is "the difference between price and value at the time of the transaction." Id. at 227. For a general survey of Rule 10b-5 damages, with illustrative cases, see id. $\$ 9.1-2$, at 225-29, 424.11-427; 3 L. Loss, supra note 5, at 1792-97 (2d ed. 1961); 6 id. at 3920-25 (2d ed. Supp. 1969).

A possible $\$ 10$ (b) damage formula is suggested in 51 N.Y.U.L. REv. 1050, 1076-78. The author proposes the damage standard suggested by the Liangs, see note 78 infra (difference between actual sales price and sales value within a reasonable time thereafter), in situations where a plaintiff "can show that but for the defendant's breach of the rule, he would have dealt with a broker-dealer with more favorable margin policies." 51 N.Y.U.L. REv. at 1076. In cases where "a customer alleges that but for the broker-dealer's unlawful act, the customer would not have opened a margin account at all," the author suggests that a plaintiff's damages be represented by "the difference between the price originally paid for the stock, and the price of the stock when he finally sold it at a loss." Id. at 1076-77. 
be based on the luck of the marketplace rather than on the harm suffered. ${ }^{78}$ Speculative recoveries would thus be controlled by such factors as the market behavior of stocks held on margin, ${ }^{79}$ the circumstance of how near a particular investor happened to be to a margin $\mathrm{call}^{\mathrm{s}}{ }^{\mathrm{s}}$ and the purely individual response of each investor to a request for more funds. ${ }^{81}$ In effect, such a damage standard for Rule 10b-16 would underwrite speculative losses and hence reward those who were both less conservative and more fortunate than other investors.

Under a more rational Rule $10 \mathrm{~b}-16$ damage formula, ${ }^{82}$ damages would be minimal. In the case of an improperly disclosed margin system, damages would result only from the customer's lack of knowledge regarding when the margin call would have been made. ${ }^{83}$ In most in-

78. The Liangs suggested a recovery formula based on the Texas Gulf Sulphur litigation, Mitchell v. Texas Gulf Sulphur Co., 446 F.2d 90 (10th Cir. 197I), cert. denied, 404 U.S. 1004 (1971). See 540 F.2d at 1110 . Such a measure of damages is inappropriate because Rule 10b-16 violations would not cause any fluctuations in the price of securities, and a recovery based on price changes in a stock would be unreasonable.

Perhaps a more equitable damage formula would be based on a refunding by the broker to the plaintiff of the amount of interest or commissions paid by him as a result of transactions in a margin account. Such a formula would more closely approximate the harm caused by margin nondisclosures. This would be somewhat analogous to recoveries in $\S 10(b)$ cases involving "churning," a practice in which brokers encourage excessive and fruitless trading in order to incrcase their brokerage fees. In such cases, courts have "generally allowed the recovery ... of the total amount of the commissions paid, but not any loss in the market value of the portfolio." $R$. Jennings \& H. Marsh, Securities Regulation Cases and Materials 690 (4th ed. 1977). See, e.g., Hecht v. Harris, Upham \& Co., 430 F.2d 1202 (9th Cir. 1970). Such a Rule 10b-16 damage formula, however, would seldom yield results. See pp. 393-94 \& notes $82-86$ infra.

79. That a stock is bought on margin by many people may tend to make it more volatile. The factors of natural and margin-induced volatility would make certain stocks subject to rapid swings in price. Given the damage formula put forth in Liang, maximum recoveries would be possible when the stock in question fell, was sold, and then rose very rapidly.

80. No matter how much the margin client might have been deceived, he would only be damaged if he were sold out by his broker at a loss. If the margin customer profits by his margin trading, the nondisclosure has not caused him apparent harm. In other words, if he never came near getting a margin call because his stocks performed moderately well, he would be unable to establish Rule $10 \mathrm{~b}-16$ damages.

81. Conservative or liquid investors who responded to a margin call with the required cash or additional collateral may be unable to recover under Rule 10b-16. Yet they may still have been harmed because they had to sell assets, borrow money, or suffer some other financial embarrassment in order to obtain the necessary funds.

82. See note 78 supra.

83. This is so because the Rule $10 \mathrm{~b}-16$ violation in no way affects the price of the security. The real harm would thus come from the plaintiff's uncertainty about the timing of a margin call. Though it could be argued that any economic losses flowing from that uncertainty, such as opportunity costs of remaining liquid enough to meet the unexpected margin call, should be recompensed, there is an important factor militating against such recoveries. Since market fluctuations, which cannot be anticipated, control the timing of a call, it seems unfair to allow recoveries because of the existence of a disclosure violation that was not in any real way a cause of the plaintiff's harm. For even if the disclosure violation had not occurred, the plaintiff would still have been uncertain about the timing of a margin call. See note 39 supra. Given the nature of a Rule 
stances, it would be difficult to show that the nondisclosure caused harm to the plaintiff, and recovery would thus be a sometime event. ${ }^{\$ 4}$ In the instances where damages could be proved, ${ }^{85}$ however, an action could be brought under Rule $10 \mathrm{~b}-5$ for failure to disclose material information. ${ }^{86}$ Thus Rule $10 \mathrm{~b}-16$ adds little to the section $10(\mathrm{~b})$ enforcement arsenal. At best, it is merely a catalogue of the kind of information the SEC considers material in disclosures concerning a margin account; ${ }^{87}$ at worst, it is a misleading Rule that offers plaintiffs more protection and damage recovery prospects than it can deliver.

\section{A Proposal for Regulation of Margin Interest Rates}

The inadequate protection afforded margin customers by Rule 10b16 raises serious questions about the propriety of using the securities laws, oriented as they are toward protection of the investing public and regulation of the securities markets, to implement a regulatory system inspired by an Act devised to protect financially naive consumers in general credit transactions. If Congress determines that margin investors need the disclosures required by Rule 10b-16, it

$10 \mathrm{~b}-16$ violation, all a plaintiff could prove would be that, had he known all the facts about margin call standards, he would either have traded with a different broker or not have opened a margin account at all. See 51 N.Y.U.L. REv. 1050, 1076-78. The plaintiff usually could not claim that he would not have speculated at all; merely that he could not have done so on margin. The only real damages would thus probably be the interest charges (and, possibly, the commissions) he had paid in the margin account. Such damages would be much smaller than claims based on potentially wide price fluctuations in individual securities purchased.

84. The plaintiff would have to establish that he would have acted differently had he known all the facts about the margin account. This would doubtless be a difficult burden, as courts are seldom sympathetic to claims under the securities laws based on arguments that plaintiff would have done something differently but for the nondisclosure violation. One of the reasons for this attitude is an awareness of the proof problems caused by allowing such claims. See, e.g., Blue Chip Stamps v. Manor Drug Stores, 421 U.S. 723 (1975) (recovery to Rule 10b-5 plaintiff based on claim that he would have bought stock denied). Assuming plaintiffs were allowed to argue such theories, they would have to establish that they relied on the improperly disclosed information, which somehow caused their economic loss. Reliance and causation are not easy $\$ 10(\mathrm{~b})$ elements to prove. See notes $64 \& 65$ supra.

85. These damages would involve interest rates and commissions. See note 83 supra.

86. Any Rule 10b-16 nondisclosure violation which causes economic harm would by its very nature be a nondisclosure of information that was material to the plaintiff. See note 63 supra. Hence, recoverable Rule $10 \mathrm{~b}-16$ violations would be violations of Rule $10 \mathrm{~b} \cdot 5$.

87. The difficulty with Rule $10 \mathrm{~b}-16$ comes from the fact that any violation of the Rule that leads to recoverable damages is also a violation of Rule $10 \mathrm{~b}-5$, because the information not disclosed was material to the plaintiff. See note 86 supra. The rest of Rule $10 \mathrm{~b}-16$ is relatively useless. Violations of other portions of the Rule, which could not be brought as Rule $10 \mathrm{~b}-5$ violations, are not as a practical matter enforceable through private suits since they do not generate any recoveries. They would thus only be the grounds for SEC enforcement actions. 
could achieve a more rational system geared toward fulfillment of the legislative goals of both the Truth in Lending Act and the Securities Exchange Act of 1934. Such a system of dealing with margin credit abuses would offer two separate remedies, each of which corresponds to a type of abuse. These remedies would derive from the Truth in Lending Act and the SEC's Rule 10b-5, respectively.

Such a bifurcated system requires repeal of the exemption of margin credit from the purview of the Truth in Lending Act. Placing stock and commodity margin transactions under the Act would allow widespread but limited recoveries for all interest rate abuses, regardless of whether they are securities law violations. Reliance on Truth in Lending would also avoid the standing and materiality problems of the securities laws and guarantee recovery to all victims of nondisclosures, regardless of their individual trading practices.

Rule 10b-16 should be withdrawn as a separate section 10(b) regulation. Rule $10 \mathrm{~b}-5{ }^{88}$ however, would remain as a remedy for abuses in connection with margin transactions. In cases where genuine damages going beyond mere nondisclosure of interest rates had occurred in connection with margin transactions, suits alleging margin credit violations could be brought as Rule 10b-5 causes of action. Theory and some precedent already exist for use of Rule $10 \mathrm{~b}-5$ in this manner, ${ }^{89}$ as is indicated by the SEC's assertion that margin violations constitute "manipulative devices" as that term is used in section 10(b) of the 1934 Act.90

With the repeal of Rule 10b-16, SEC regulation of collateral disclosure requirements would cease. ${ }^{91}$ The transfer of interest rate regulation to the Truth in Lending Act would reflect the general intent of Congress concerning disclosure of credit terms and would tend to treat margin customers the same as other consumers of credit, within the limits set by the Act. This change of jurisdiction from one statute to another would neither conflict with nor diminish the authority and

88. This regulation, unlike Rule $10 \mathrm{~b} \cdot 16$, has been extensively developed by courts. See pp. 388-90, 392 and notes 59-66 \& 73-77 supra.

89. Various misrepresentations with regard to margin accounts have been the basis for Rule 10b-5 claims. See Smith v: Bear, 237 F.2d 79 (2d Cir. 1956) (incorrect information as to margin that would be required); Glickman v. Schweickhart \& Co., 242 F. Supp. 670 (S.D.N.Y. 1965) (representation that complete financing would be no riskier than regular margin).

90. The SEC suggested that nondisclosure of certain facts about a margin account may represent a violation of the antifraud provisions of the securities laws. See George D. Curtis, [1972] FED. SEc. L. REP. (CCH) If 78,651 (SEC 1971) (failure of broker-dealer to disclose time limit within which customer must supply additional margin).

91. As a result, the system and canons of regulation governing deposit of collateral and margin maintenance calls would be left as they are now, with the interplay of Federal Reserve Board and stock or commodity exchange control. See note 8 supra. 
reach of the Securities Exchange Act of 1934, which exhibits, in section $10(\mathrm{~b})$ and elsewhere, an intention on the part of Congress that investors be protected from fraud in connection with securities transactions. Rather, the scheme proposed would enhance the effectiveness and rationality of the 1934 Act in this area, for it would terminate an unsatisfactory experiment which forced the Commission to draft a rule serving two very different congressional policies.

\section{Conclusion}

The dual remedy system outlined above would represent a rational response to Congress's perception that margin investors need to be protected by federally mandated disclosure. Although it is far from clear that margin customers as a group are so powerless economically that they need congressional protection, if protection is needed the disclosures required by Rule $10 \mathrm{~b}-16$ are of little value. Before reasserting direct federal control over this facet of the securities industry, Congress should investigate more carefully the needs of margin traders as a class and reconsider the value of disclosures in margin transactions, far removed as they are from the small consumer credit purchases with which Truth in Lending is concerned. Such an investigation, which was not undertaken in 1967 by either Congress or the SEC, may well prompt the legislators to leave margin transactions outside the reach of disclosure requirements entirely. 